\title{
An adeno-associated viral vector transduces the rat hypothalamus and amygdala more efficient than a lentiviral vector
}

\author{
Marijke WA de Backer ${ }^{1}$, Carlos P Fitzsimons², Maike AD Brans ${ }^{1}$, Mieneke CM Luijendijk1, Keith M Garner1, \\ Erno Vreugdenhil ${ }^{2}$ and Roger AH Adan*1
}

\begin{abstract}
Background: This study compared the transduction efficiencies of an adeno-associated viral (AAV) vector, which was pseudotyped with an AAV1 capsid and encoded the green fluorescent protein (GFP), with a lentiviral (LV) vector, which was pseudotyped with a VSV-G envelop and encoded the discosoma red fluorescent protein (dsRed), to investigate which viral vector transduced the lateral hypothalamus or the amygdala more efficiently. The LV-dsRed and AAV1-GFP vector were mixed and injected into the lateral hypothalamus or into the amygdala of adult rats. The titers that were injected were $1 \times 10^{8}$ or $1 \times 10^{9}$ genomic copies of AAV1-GFP and $1 \times 10^{5}$ transducing units of LV-dsRed.

Results: Immunostaining for GFP and dsRed showed that AAV1-GFP transduced significantly more cells than LV-dsRed in both the lateral hypothalamus and the amygdala. In addition, the number of LV particles that were injected can not easily be increased, while the number of AAV1 particles can be increased easily with a factor 100 to 1000 . Both viral vectors appear to predominantly transduce neurons.

Conclusions: This study showed that AAV1 vectors are better tools to overexpress or knockdown genes in the lateral hypothalamus and amygdala of adult rats, since more cells can be transduced with AAV1 than with LV vectors and the titer of AAV1 vectors can easily be increased to transduce the area of interest.
\end{abstract}

\section{Background}

Viral vectors are used as tools to introduce genes or short-hairpin RNAs (shRNAs) into the brain in order to unravel the role of genes. The advantages of viral vectors are that they can be injected locally and that they establish long term expression of a gene or shRNA. Several viral vectors have been tested in vivo in the central nervous system, such as adeno-associated viral (AAV), lentiviral (LV), adenoviral (AdV) and herpes simplex viral (HSV) vectors [1-4]. To date, studies in the rodent hypothalamus and amygdala mainly have used AAV or AdV and to a lesser extent $L V$ vectors [5-10]. In this study we compared the transduction efficiencies of AAV and LV vectors. The LV and AAV vector used in this study both used the CMV promoter to drive the expression of a fluorescent marker, dsRed or GFP respectively. The AAV and

* Correspondence: r.a.h.adan@umcutrecht.nl

${ }^{1}$ Rudolf Magnus Institute of Neuroscience, Department of Neuroscience and Pharmacology, University Medical Centre Utrecht, Utrecht, the Netherlands

Full list of author information is available at the end of the article
LV vectors were pseudotyped; the AAV vector was pseudotyped with AAV1 and the LV vector was pseudotyped with VSV-G. To date, at least 12 serotypes of AAV are discovered (AAV1-AAV12) [11-20] that probably use different receptors to enter cells [21-28]. Nevertheless, for most serotypes the cell entry receptors are still unknown. Until now the most widely used serotype is AAV2. However, recent studies have shown that AAV1 and AAV8 coated vectors transduce more neurons than AAV2 coated vectors in vivo in several brain areas, such as the rat striatum, hippocampus, midbrain [29-35]. We have chosen to use an AAV1 pseudotyped vector, because we previously have shown that this serotype is more efficient in transduction of neurons in the adult rat hypothalamus than an AAV2 encapsidated vector [36]. For the LV vector we chose the vesicular stomatitis virus glycoprotein (VSV-G), because it was shown to have a broad tropism for all kinds of neurons. However there are also other 
envelope proteins which can be used to pseudotype LV vectors and target the CNS [37].

It is important to know which viral vector, AAV or LV, is most efficient in transduction of brain areas involved in energy homeostasis, because then it is possible to efficiently alter gene expression in specific brain nuclei to further investigate the function of genes involved in feeding behavior. The lateral hypothalamus (LH) and amygdala (AM) are important brain areas involved in energy homeostasis [38]. Previously, we have shown that AAV vectors can be used to alter behavior in rats. AAVmediated overexpression of neuropeptide $\mathrm{Y}$, agouti and agouti-related peptide in the hypothalamus increased parameters such as body weight and food intake [36,3941]. However, a study by another group showed that LV vectors can be also used to alter gene expression in the hypothalamus and thereby alter body weight [42]. Thus, AAV and LV vectors are able to change gene expression and behavior after transduction of neurons in the rat hypothalamus. However, it is unclear whether AAV or LV vectors are more efficient in transduction of the rat hypothalamus or amygdala. Therefore, this study compared the transduction efficiencies of a $L V$ and an AAV vector in the $\mathrm{LH}$ and AM of adult rats.

\section{Results}

\section{In vitro testing of antibodies}

To confirm that GFP and dsRed antibodies were able to detect the respective proteins with similar efficiencies, 293T cells were transfected with constructs encoding for CMV-GFP and/or CMV-dsRed (Figure 1A, B). Since the promoter driving the expression of the fluorescent proteins was the same, we expected similar levels of expression. The endogenous fluorescence of GFP and dsRed was compared with the immunostained fluorescence. The cells transfected with only one construct showed colocalization of endogenous fluorescence and immunostained fluorescence (Figure 1C, D). In addition, cells cotransfected with CMV-GFP and CMV-dsRed showed colocalization of both immunohistochemistry signals (Figure $1 \mathrm{E})$. The pictures showed that red fluorescent signals, endogenous or immunostained, were at least threefold stronger in intensity than green fluorescent signals.

\section{AAV1-GFP and LV-dsRed transduction in vitro}

The AAV-GFP plasmid was pseudotyped with an AAV1 coat, because that coat was previously shown to be more effective in transduction of hypothalamic nuclei, such as the LH, than AAV2 coated vectors [36]. It is still unknown which entry receptors AAV1 uses to enter cells and it is therefore unknown which cell line is most optimal for determining transducing units. Nevertheless, we performed a serial dilution with AAV1-GFP on HT-1080 cells to obtain an indication of transducing units. These

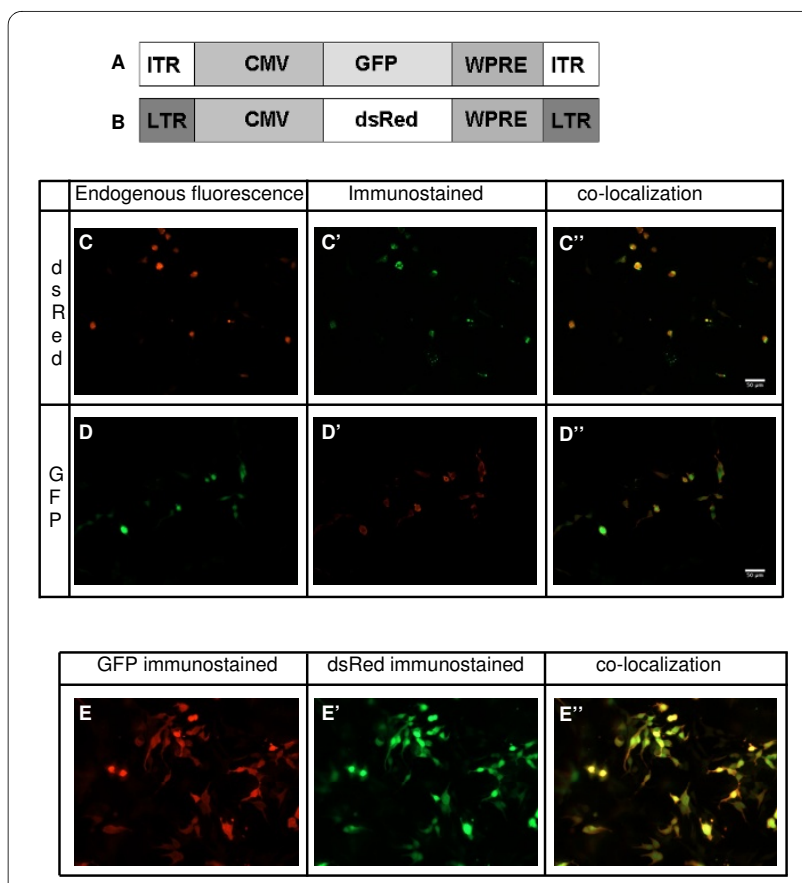

Figure 1 In vitro testing of the antibodies against GFP and dsred. A: schematic overview of AAV vector used. B: schematic overview of LV vector used. C: shows endogenous dsRed fluorescence (red) in 293T cells transfected with CMV-dsRed. C':shows immunostaining for dsRed (green) in these cells. C": shows the co-localization of the immunostained and endogenous fluorescence (yellow). D: shows endogenous fluorescence (green) in 293T cells transfected with CMV-GFP. D': shows immunostaining for GFP (red) and ' '" shows the overlay of D and D' (green nucleus with red cytoplasma). E: 293T cells co-transfected with CMV-GFP and CMV-dsred were immunostained for GFP (red (E)) and dsRed (green $\left.\left(\mathbf{E}^{\prime}\right)\right)$. These stainings overlap (yellow $\left.\left(\mathbf{E}^{\prime \prime}\right)\right)$. Scalebar is 50 $\mu \mathrm{m}$.

results showed that the titer of AAV1-GFP was $5 \times 10^{8}$ t.u./ml, which is substantially lower than the $6.6 \times 10^{13}$ g.c. $/ \mathrm{ml}$. The LV-dsRed had a titer of $3.9 \times 10^{8} \mathrm{t} . \mathrm{u} . / \mathrm{ml}$.

Before mixing the two viruses, the preparations were diluted. AAV was diluted to $2 \times 10^{8}$ and $2 \times 10^{9}$ g.c. $/ \mu \mathrm{l}$, thus $1.5 \times 10^{3}$ and $1.5 \times 10^{4}$ t.u. $/ \mu \mathrm{l}$ on $\mathrm{HT}-1080 \mathrm{respec}-$ tively. LV-dsRed was diluted to $2 \times 10^{5}$ t.u./ $\mu$ l. Subsequently the diluted viruses were mixed $1: 1$ and $1 \mu \mathrm{l}$ of this mix was injected in each brain area. This resulted in $1 \times$ $10^{8}$ or $1 \times 10^{9}$ g.c. $\left(7.5 \times 10^{2}\right.$ or $7.5 \times 10^{3}$ t.u. $)$ of AAV1GFP and $1 \times 10^{5}$ t.u. of LV-dsRed per site.

\section{Transduction of the LH by AAV1-GFP and LV-dsRed}

To determine the transduction efficiencies of AAV and $\mathrm{LV}$ vectors in the $\mathrm{LH}$ the animals were perfused four weeks after injection with viral vectors. Immunostaining for GFP and dsRed showed positive staining in the injection tract. These were probably apoptotic cells and were not included in our quantification (Figure 2, upper panel). Counting of all GFP and dsRed immunostained positive cells revealed that AAV1-GFP, at $1 \times 10^{8}$ g.c., transduced 


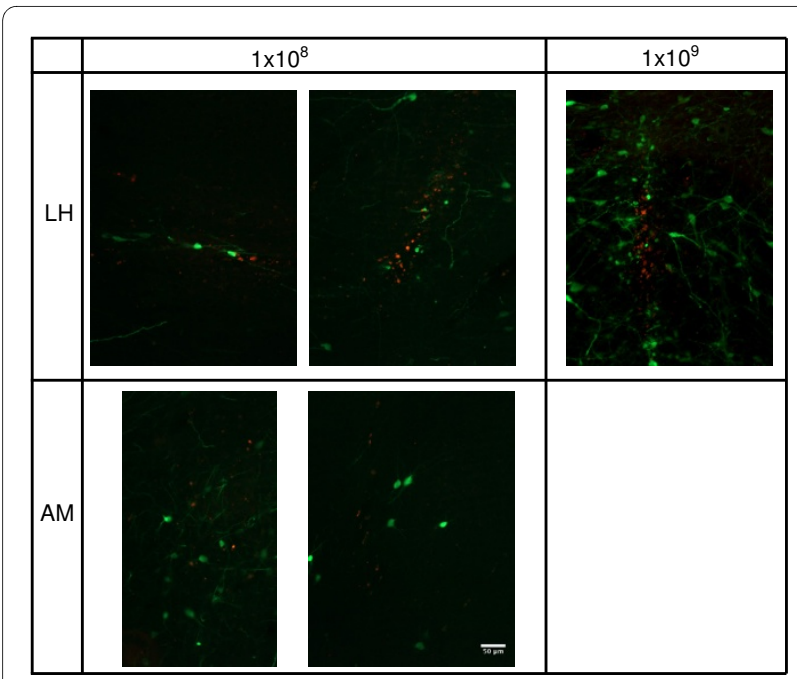

Figure 2 In vivo transduction of the LH and AM by AAV1-GFP and LV-dsRed. The titer of LV-dsRed was kept constant at $1 \times 10^{5}$ t.u., while the titer of AAV1-GFP was $1 \times 10^{8}$ or $1 \times 10^{9}$ g.c. Immunostaining for GFP is shown in green and for dsRed in red.

significantly more cells in the LH compared with LV-GFP, at $1 \times 10^{5}$ t.u. (Figure 3). The total area transduced by AAV1-GFP at the injection site was $3338( \pm 599) \mu^{2}$ and an area of $2441( \pm 403) \mu \mathrm{m}^{2}$ was transduced by LV-dsRed. As expected, an increase in titer of AAV1-GFP from $1 \times$ $10^{8}$ to $1 \times 10^{9}$ g.c. in the $\mathrm{LH}$ resulted in 14.2 -fold increase in the area transduced at the injection site; the total transduced area at the injection site increased from 3338 ( \pm 599) $\mu \mathrm{m}^{2}$ to $47525( \pm 10822) \mu \mathrm{m}^{2}(p=0.0005)$. In the LH AAV1-GFP predominantly transduced neurons, because GFP and NeuN co-localize (Figure 4A, B) and LV-dsRed

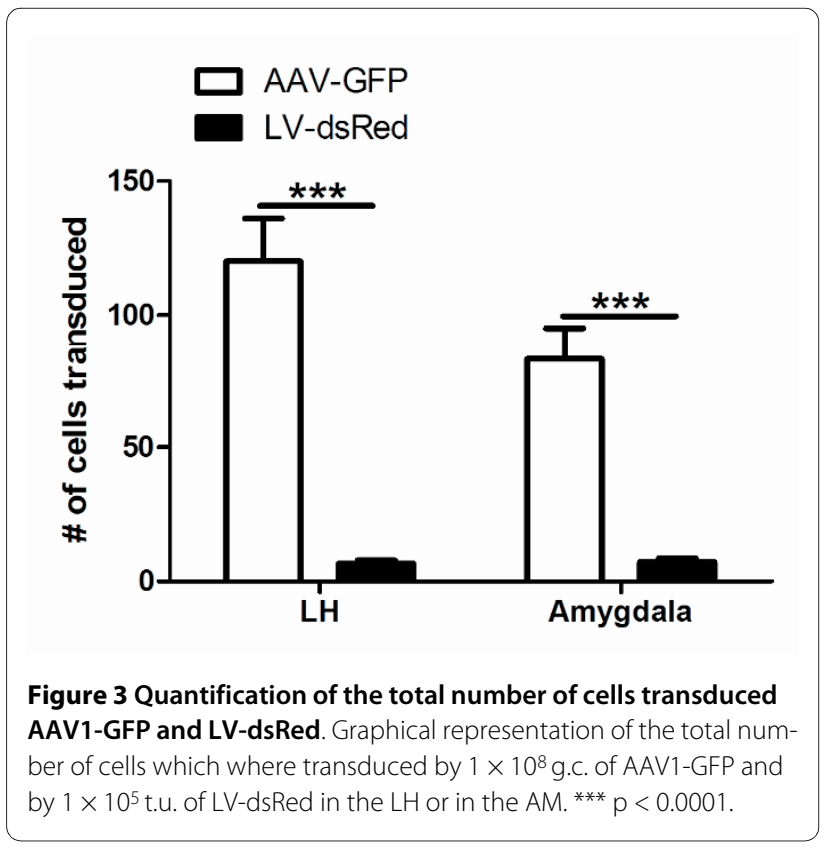

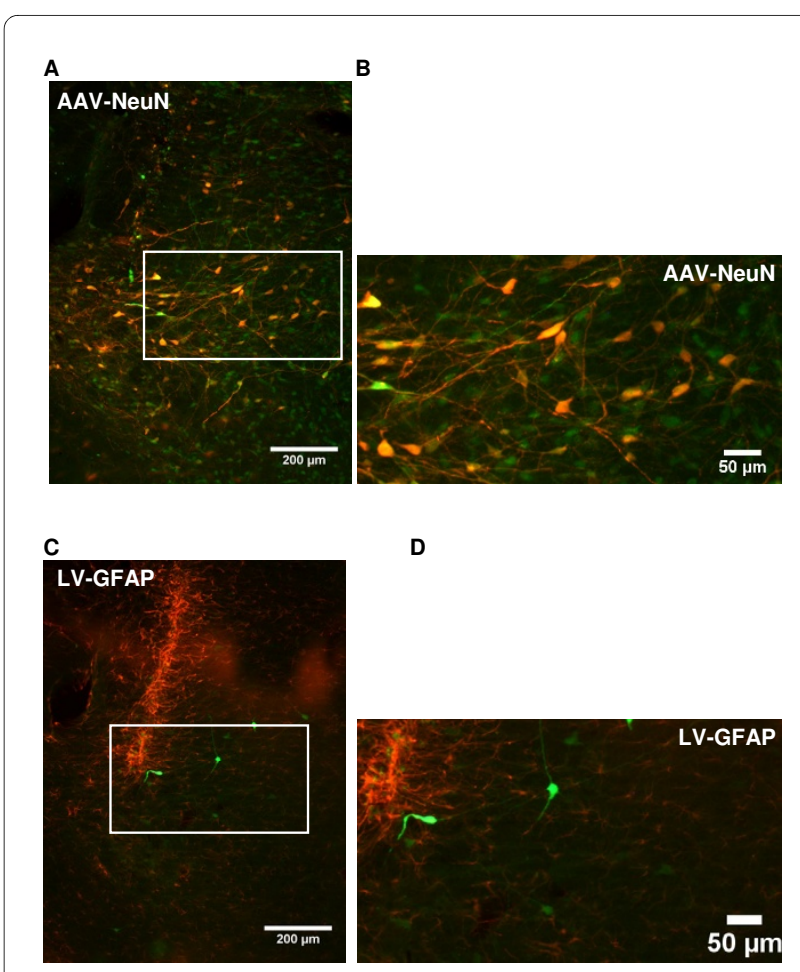

Figure 4 Co-localization of GFP and NeuN and dsRed and GFAP in the LH and AM. A: shows that AAV1-GFP (red, $\left.1 \times 10^{9}\right)$ and NeuN (green) co-localize in the LH. B: shows a close-up of AA1V-GFP and NeuN co-localization. C: shows no co-localization of dsRed (green) and GFAP (red) in the LH. D: shows no overlap between LV-red (green) and GFAP (red).

probably also transduced mainly neurons, because dsRed and GFAP did not co-localize (Figure 4C, D).

\section{Transduction of the AM by AAV1-GFP and LV-dsRed}

In addition, we studied the transduction efficiencies of AAV1-GFP and LV-dsRed in the AM (Figure 2, lower panel). Similar to the LH, AAV1-GFP transduced significantly more cells than LV-dsRed in the AM (Figure 3). The number of cells transduced by AAV1 or LV in the AM was comparable to the numbers transduced in the LH. In the AM AAV1 and LV vector also predominantly transduced neurons, however some cells transduced with AAV1-GFP did not co-localize with NeuN and had a microglia appearance.

\section{Discussion}

This study showed that an AAV1 vector transduced significantly more cells in the $\mathrm{LH}$ and AM of rats than a LVVSV-G vector. This is in agreement previous studies which showed low levels of transgene expression after injection of $1 \mu \mathrm{l}$ of LV vectors in other rat brain nuclei, namely the red nucleus [43] and the retina [44]. In contrast, several studies reported substantial levels of transduction by LV in the rat striatum and hippocampus, 
however, these groups injected larger volumes of LV, namely 2 or $3 \mu \mathrm{l}$ [45-47]. In addition, LV vectors have been reported to efficiently transduce cells in the mouse hippocampus and striatum $[48,49]$ and AAV and LV vectors were reported to transduce approximately similar numbers of cells after injection in mouse hippocampus or hippocampal slices [50,51]. These data indicate that there may be species differences and/or brain area differences, which may contribute to variations in transduction efficiencies by $L V$ and AAV vectors in rat and mouse brain.

The titer of our AAV1-GFP preparation was $6.6 \times 10^{13}$ g.c. $/ \mathrm{ml}$, which is a titer in the range that we usually obtain with AAV production. The number of transducing units/ $\mathrm{ml}$ will be lower than genomic copies/ $\mathrm{ml}$ since not all vector DNA is properly packaged into infectious particles. The optimal cell line for determining the t.u./ml of AAV1 preparations is unknown. We assessed the t.u./ml of AAV1-GFP on HT-1080 cell line. The titer of AAV1-GFP was $5 \times 10^{8}$ t.u. $/ \mathrm{ml}$, and this prep was diluted 330 times, to $1.3 \times 10^{3} \mathrm{t}$.u./ $\mu \mathrm{l}$ before mixing with LV-dsRed. The LVdsRed was only diluted 2 times to $2 \times 10^{5}$ t.u./ $\mu$ l. Since the number of t.u. of AAV1-GFP injected was much lower than the t.u. of LV-dsRed, we conclude that AAV1 is more efficient in transduction of the LH and AM than LV-VSVG. However, it has to be kept in mind that comparison of t.u. of LV-VSV-G and AAV1 vector preparations on cell lines is complicated, because the vectors probably use different, still unknown, entry receptors and different cell lines have different surface receptors. For example, one dose of AAV1/2 vectors has different t.u. values on different cell lines [52]. In addition, the t.u. of LV-dsRed preparation was assessed in the presence of polybrene, which enhances transduction [53], however, polybrene was not added when $L V$-dsRed was injected in vivo.

In the LH AAV1-GFP at $1 \times 10^{8}$ g.c. al ready transduced more cells than LV-dsRed. When the titer of AAV1-GFP was increased a ten-fold, the area transduced and the numbers of neurons transduced were increased accordingly. This indicates that increasing the titer is a valid method to increase the number of transduced neurons.

We only observed 6-7 dsRed positive cells after injection of $1 \times 10^{5}$ t.u. of LV. Thus, ideally the titer of LVdsRed should be increased to transduce more cells in the LH and AM. The methods we used for LV preparation and titer determination are standard procedures in the field. Normally, titers of concentrated LV vectors are reported to be in the range of $5 \times 10^{7}$ to $1 \times 10^{9}$ t.u. $/ \mathrm{ml}$ $[45,48,54]$. Thus compared with results from others, $3.9 \times$ $10^{8} \mathrm{t} . \mathrm{u} . / \mathrm{ml}$ is a high titer. Therefore, it is technically difficult to increase the LV titer to transduce more neurons in the AM and $\mathrm{LH}$ of rats.

The differences in transduction by AAV1-GFP and LVdsRed in the LH and AM may be explained by the fact that the vectors probably used different receptors to enter cells. The LV-dsRed used in this study was pseudotyped with VSV-G. VSV-G transduces many cell types from different species, but it is still unknown how VSV-G enters these cells. For a long time it was thought that phosphatidylserine (PS) was the receptor to mediate membrane fusion [55]. However, more recent data indicated that PS is not the entry receptor [56]. AAV-GFP was pseudotyped with AAV1 capsid proteins. The entry receptor for AAV1 also is unknown, but there are indications that $\alpha-2,3$ and $\alpha-2,6 \mathrm{~N}$-linked sialic acids facilitate transduction by AAV1 vectors [23].

Exchanging GFP and dsRed genes between LV and AAV vector (thereby obtaining AAV-dsRed and LV-GFP) probably will not alter the transduction efficiencies which we observed in this study, since the promoter and other parts of the vectors including the viral coat are unchanged. Previous studies have compared expression of GFP and dsRed in LV or AAV vectors and showed that the expression profile remained the same when only the fluorescent markers were changed; co-injection of two vectors (e.g. LV-GFP and LV-dsRed) showed that expression of both vectors largely overlapped [45,57].

The co-localization of AAV1 and NeuN showed that AAV1 predominantly transduced neurons in the $\mathrm{LH}$ and AM. This is in agreement with previous studies which showed that AAV1 predominantly transduced neurons in different rat brain regions at all investigated time points after injection $[29,33,34]$. The LV and GFAP immunohistochemistry signals did not co-localize indicating that LV at 4 weeks post-injection probably transduced neurons. This confirms data from previous studies where LV predominantly co-localized with $\mathrm{NeuN}$ in the rat brain $[45,46,58,59]$.

\section{Conclusion}

When a substantial part or the entire LH or AM of rats needs to be transduced AAV1 vectors are preferred over $L V$ vectors, since more neurons can be transduced with AAV1 than with LV-VSV-G vectors and the titer of AAV preparations can easily be increased.

\section{Methods}

\section{Cell lines and constructs}

Human embryonic kidney (HEK) 293T cells were maintained at $37^{\circ} \mathrm{C}$ with $5 \% \mathrm{CO}_{2}$ in Dulbecco's modified Eagles medium (DMEM) supplemented with $10 \%$ fetal calf serum (FCS), $2 \mathrm{mM}$ glutamine, 100 units $/ \mathrm{ml}$ penicillin, 100 units/ml streptomycin and non-essential amino acids.

pAAV-CMV-GFP was constructed by removing the CMV promoter with a part of the GFP gene from pTRCGW [60] through digestion with KpnI and BsrGI. Subsequently this fragment was ligated into a KpnI BsrGI 
digested backbone of pAAV-CBA-GFP (kind gift from $\mathrm{M}$. Sena-esteves [61]). This digestion removed the CBA promoter and a part of the GFP gene.

The construction of LV-CMV-dsRED was previously described [62].

To check the specificity and intensity of staining of the GFP and dsRed antibodies, $2.5 \mu \mathrm{g}$ of pPRIME-CMV-GFP and pPRIME-CMV-dsRed [63] were transfected, alone or together, on $10 \mathrm{~cm}$ dishes with polyethylenimine (PEI). The morning after transfection the cells were trypsinized and seeded in 24 wells plates containing poly-L-lysine coated glass cover slips. Seventy-two hours after transfections cells were washed with phosphate buffered saline (PBS), fixated for 20 minutes with $4 \%$ paraformaldehyde (PFA) and stored in PBS at $4^{\circ} \mathrm{C}$ until immunohistochemistry was performed.

\section{Virus production and purification}

AAV production was performed with $15 \times 15 \mathrm{~cm}$ dishes $293 \mathrm{~T}$ cells, which were $80-90 \%$ confluent at day of transfection. Two hours before transfection, the 10\% FCSDMEM was replaced with 2\% FCS-DMEM. The transfections were performed with polyethylenimine (PEI) as described by Reed S.E. et al. [64]. pAAV-CMV-GFP was co-transfected with the helper plasmid pDP1 [65] (Plasmid factory, Bielefeld, Germany) in a molar ratio of 1:1. The transfection mix remained on the cells until the next day, then the $2 \%$ FCS-DMEM was refreshed. The production and purification was essentially performed as described by Zolotukhin et al. [66]. Briefly, sixty hours after transfection, the cells were harvested in their medium, centrifuged and washed with PBS containing 5 $\mathrm{mM}$ ethylenediaminetetraacetic acid (EDTA). Finally, the cells were collected in $12 \mathrm{ml}$ ice cold buffer $(150 \mathrm{mM}$ sodium chloride $(\mathrm{NaCl}), 50 \mathrm{mM}$ 2-amino-(hydroxymethyl)-1,3-propanediol (Tris), $\mathrm{pH} 8.4$ ) and stored at $-20^{\circ} \mathrm{C}$ until further use. Subsequently, the cells were freezethawed twice, incubated for 30 minutes with 50 units $/ \mathrm{ml}$ Benzonase (Sigma, the Netherlands) at $37^{\circ} \mathrm{C}$ and centrifuged. After centrifugation, the supernatant was loaded onto an iodixanol gradient $(60 \%, 40 \%, 25 \%, 15 \%$, supernatant (Optiprep, Lucron bioproducts, Belgium)) in quickseal tubes (Beckman Coulter, The Netherlands). After 1.25 hour of ultracentrifugation $\left(70.000 \mathrm{rpm}\right.$ at $\left.18^{\circ} \mathrm{C}\right)$ in Ti70 rotor (Beckman Coulter, the Netherlands), the 40\% layer was extracted. This $40 \%$ layer was used for ionexchange chromatography with $5 \mathrm{ml}$ Hitrap Q HP columns (GE Healthcare, The Netherlands). Subsequently PCR was used to determine AAV positive fractions. The positive fractions were pooled and desalted/concentrated on Centricon Plus-20 Biomax-100 concentrator columns (Millipore, The Netherlands). The titer, in genomic copies per $\mathrm{ml}$ (g.c. $/ \mathrm{ml}$ ), was determined by qPCR with sybergreen mix in a LightCylcer (Roche) [67]. The qPCR primers were designed to detect BGHpolyA and were BGHpolyA_F: $\quad 5^{\prime} \quad$ CCTCGACTGTGCCTTCTAG; BGHpolyA_R: 5' CCCCAGAATAGAATGACACCTA. The titer obtained for AAV1-GFP was $6.6 \times 10^{13}$ genomic copies (g.c.)/ml. In addition we also performed a serial dilution with AAV1-GFP virus on HT1080 cells, to obtain an indication of the transducing units in this AAV preparation. Seventy-two hours after infection GFP positive cells were counted and a titer was calculated. This serial dilution showed that a titer of $5 \times 10^{8}$ transducing units (t.u.)/ml was achieved.

Lentivirus with CMV promoter driving dsRed expression (LV-dsRED) was produced as described previously [62]. In short, 293T cells were transfected using the ViraPower Lentiviral Expression System (Invitrogen, Breda, the Netherlands) according to manufacturer's instructions. Forty-eight hours after transfection virus containing supernatant was harvested, centrifuged at $2.000 \mathrm{rpm}$ for 3 minutes to remove cell debris and concentrated by two rounds of ultracentrifugation $(19.400$ $\mathrm{rpm}, 4^{\circ} \mathrm{C}, 2$ hours each), resuspended in PBS, aliquoted and stored at $-80^{\circ} \mathrm{C}$ until use. Virion titers were measured by real-time PCR and titers were calculated from those and verified by dsRed expression in $293 \mathrm{~T}$ cell with addition of polybrene [68]. Titer of LV-dsRed was $3.9 \times 10^{8}$ t.u/ml.

\section{Animals}

Twelve male Wistar rats of 220-250 g, were purchased from Charles River (Crl-Wu, Germany). All rats were individually housed in filtertop cages with ad libitum access to food (CRM pellets; Special Diet Services, Whitham, Essex, UK) and water. Animals were kept in a temperature- and humidity-controlled room $\left(21 \pm 2^{\circ} \mathrm{C}\right)$ with a $12 \mathrm{~h}$ light/dark cycle (lights on at 7:00 A.M.). All experimental procedures were approved by the Committee for Animal Experimentation of the University of Utrecht (Utrecht, The Netherlands).

Just before stereotactic injections AAV1-GFP was diluted in PBS to $2 \times 10^{8}$ g.c $/ \mu \mathrm{l}$ or $2 \times 10^{9}$ g.c. $/ \mu \mathrm{l}$ and LVdsRed was diluted to $2 \times 10^{8} \mathrm{tu} / \mu \mathrm{l}$. The diluted AAV and $L V$ vectors were mixed $1: 1$ and $1 \mu$ of this mixture was injected in the LH or in the AM of rats. The injections were performed with a micro-infusion pump. The injection speed was $0.2 \mu \mathrm{l} /$ minute. After the injection the needle remained in the injection site for 10 minutes.

After $11 / 2$ week of acclimatization surgery was performed under fentanyl/fluanisone (Hypnorm ${ }^{\circ}$, Janssen Pharmaceutica, Beerse, Belgium, $0.1 \mathrm{ml} / 100$ g intramuscular) and midazolam (Dormicum ${ }^{\circ}$, Roche, Woerden, the Netherlands, $0.05 \mathrm{ml} / 100 \mathrm{~g}$ intraperitonal) anesthesia. Carprofen (Rimadyl ${ }^{\circ}$, Pfizer Animal Health, Capelle a/d Ijssel, the Netherlands, $0.01 \mathrm{ml} / 100$ g s.c.). Four rats were injected bilaterally in the LH (coordinates AP-2.6, 
$\mathrm{ML}+2.0, \mathrm{DV}-8.6)$ with $1 \mu \mathrm{l}$ of AAV-LV mixture containing $1 \times 10^{8} \mathrm{gc}$ of AAV1-GFP and $1 \times 10^{8}$ tu of LV-dsRed. Another four rats also received $1 \mu \mathrm{AAV}-\mathrm{LV}$ mixture in the LH. Here LV-dsRed remained $1 \times 10^{8} \mathrm{tu}$, however, the titer of AAV1-GFP was raised 10 times to $1 \times 10^{9} \mathrm{gc}$. In addition, four rats received injections in the central AM (coordinates AP-2.1, ML+4.0, DV -8.0) with a mixture of $1 \times 10^{8} \mathrm{gc}$ of AAV1-GFP and $1 \times 10^{8} \mathrm{tu}$ of LV-dsRed. Four weeks after the injections the rats were anesthetized and perfused with $4 \%$ PFA containing $0.05 \%$ glutaraldehyde. Subsequently, the brains were isolated and placed in $4 \% \mathrm{PFA}$ overnight at $4^{\circ} \mathrm{C}$. The next morning the brains were placed in PBS and stored at $4^{\circ} \mathrm{C}$ until further use. The perfused brains were sectioned on a vibratom (Leica) at $40 \mu \mathrm{m}$ in series of 10 .

\section{Immunohistochemistry}

Every tenth $40 \mu \mathrm{m}$ section was used for GFP-dsRed staining. The free floating sections were washed 3 times with PBS, permeabilized for 30 minutes in PBS supplemented with $0.5 \%$ triton $\mathrm{X}-100$ at room temperature (RT), blocked for 1 hour in PBS with 1.5\% normal goat serum (NGS) at RT and incubated overnight in PBS supplemented with mouse monoclonal anti-dsRed (1:400, Clontech), rabbit polyclonal anti-GFP (1:1000, Invitrogen) and $1.5 \%$ NGS at $4^{\circ} \mathrm{C}$. The next morning sections were washed 3 times for 10 minutes with PBS and incubated for 1 hour with secondary antibodies (ALEXA 555 conjugated goat anti mouse (1:500) and ALEXA 488 conjugated goat anti rabbit (1:1000) both Invitrogen) in $1.5 \%$ NGS at RT. After 3 times 10 minutes wash with PBS, the sections were transferred to microscope slides and kept over night in the dark to dry. All sections were embedded in $90 \%$ glycerol and stored flat at $4^{\circ} \mathrm{C}$.

A similar protocol was used for GFP-NeuN double staining, the antibody of mouse NeuN (Chemicon) was used at 1:2000 dilution and goat anti-mouse ALEXA 555 was used at 1:1000 dilution.

For dsRed-GFAP staining the sections were washed $3 \times$ in PBS and incubated in sodium citrate buffer $(10 \mathrm{mM}$ tri-sodium citrate, $\mathrm{pH}=8.5$ ) for 30 minutes at $70^{\circ} \mathrm{C}$. Subsequently, the sections were allowed to cool down to room temperature, washed 3 times for 5 minutes with PBS, blocked in PBS+ 3\% fetal calf serum (FCS) for 60 minutes and incubated overnight in PBS supplemented with mouse anti-dsRed (1:500), rabbit anti-GFAP (1:4000, DAKO), $0.2 \%$ triton X-100 and $1 \%$ FCS at $4{ }^{\circ} \mathrm{C}$. The next morning the sections were washed 3 times for 10 minutes in PBS and incubated in PBS supplemented with goat anti-rabbit-ALEXA 488 (1:250), goat anti-mouse-ALEXA 555 (1:500), $0.2 \%$ triton-X100 and 1\% FCS for 1 hour. After 3 times 10 minutes wash with PBS, the sections were transferred to microscope slides and kept over night in the dark to dry. All sections were embedded in $90 \%$ glycerol and stored flat at $4^{\circ} \mathrm{C}$.

\section{Imaging and data analysis}

The number of positive cells for GFP and dsRed were counted in every section, except the positive cells in the injection tract which are probably macrophages.

The MCID system was used to digitize pictures from sections containing endogenous or immunohistochemistry signals.

GraphPad Prism was used for data analysis and treatment effects were evaluated with two-tailed $t$-test.

\section{Competing interests}

The authors declare that they have no competing interests.

\section{Authors' contributions}

$M d B$ constructed the AAV vector and produced the AAV vector with the help of $K G$. MB and $M L$ performed animal work including the stereotaxic injections. $\mathrm{MdB}$ performed and analyzed immunohistochemstry; discussed the results and prepared the manuscript. CF constructed and produced the LV vector preparation; discussed and corrected the manuscript. EV participated in the design of the study and discussed and corrected the manuscript. RA participated in experimental design and supervised the experiments, discussed results, corrected the manuscript and provided financial support. All authors have read and approved the final manuscript.

\section{Acknowledgements}

This work was supported by the Netherlands Organization for Scientific Research (NWO grant No. 90339175).

\section{Author Details}

${ }^{1}$ Rudolf Magnus Institute of Neuroscience, Department of Neuroscience and Pharmacology, University Medical Centre Utrecht, Utrecht, the Netherlands and 2 Medical Pharmacology Department, Leiden/Amsterdam Center for Drug Research, Leiden University Medical Center, Leiden University, Leiden, the Netherlands

Received: 26 February 2010 Accepted: 13 July 2010

Published: 13 July 2010

\section{References}

1. Terzi D, Zachariou V: Adeno-associated virus-mediated gene delivery approaches for the treatment of CNS disorders. Biotechnol J 2008, 3:1555-1563.

2. Lundberg C, Bjorklund T, Carlsson T, Jakobsson J, Hantraye P, Deglon N, Kirik D: Applications of lentiviral vectors for biology and gene therapy of neurological disorders. Curr Gene Ther 2008, 8:461-473.

3. Segura MM, Alba R, Bosch A, Chillon M: Advances in helper-dependent adenoviral vector research. Curr Gene Ther 2008, 8:222-235.

4. Berges BK, Wolfe JH, Fraser NW: Transduction of brain by herpes simplex virus vectors. Mol Ther 2007, 15:20-29.

5. Tiesjema B, la Fleur SE, Luijendijk MC, Adan RA: Sustained NPY overexpression in the PVN results in obesity via temporarily increasing food intake. Obesity (Silver Spring) 2009, 17:1448-1450.

6. Liu M, Thankachan S, Kaur S, Begum S, Blanco-Centurion C, Sakurai T, Yanagisawa M, Neve R, Shiromani PJ: Orexin (hypocretin) gene transfer diminishes narcoleptic sleep behavior in mice. Eur J Neurosci 2008, 28:1382-1393

7. Yang L, Scott KA, Hyun J, Tamashiro KL, Tray N, Moran TH, Bi S: Role of dorsomedial hypothalamic neuropeptide $\mathrm{Y}$ in modulating food intake and energy balance. J Neurosci 2009, 29:179-190.

8. Couturier C, Sarkis C, Seron K, Belouzard S, Chen P, Lenain A, Corset L, Dam J, Vauthier V, Dubart A, et al:: Silencing of OB-RGRP in mouse hypothalamic arcuate nucleus increases leptin receptor signaling and prevents diet-induced obesity. Proc Natl Acad Sci USA 2007, 104:19476-19481. 
9. Spiteri T, Musatov S, Ogawa S, Ribeiro A, Pfaff DW, Agmo A: EstrogenInduced Sexual Incentive Motivation Proceptivity and Receptivity Depend on a Functional Estrogen Receptor alpha in the Ventromedial Nucleus of the Hypothalamus but Not in the Amygdala. Neuroendocrinology 2010, 91:142-54.

10. Liu YF, Chen HI, Wu CL, Kuo YM, Yu L, Huang AM, Wu FS, Chuang Jl, Jen CJ: Differential effects of treadmill running and wheel running on spatial or aversive learning and memory: roles of amygdalar brain-derived neurotrophic factor and synaptotagmin I. J Physio/ 2009, 587:3221-3231

11. Gao GP, Alvira MR, Wang L, Calcedo R, Johnston J, Wilson JM: Novel adeno-associated viruses from rhesus monkeys as vectors for human gene therapy. Proc Natl Acad Sci USA 2002, 99:11854-11859.

12. Hoggan MD, Blacklow NR, Rowe WP: Studies of small DNA viruses found in various adenovirus preparations: physical biological, and immunological characteristics. Proc Natl Acad Sci USA 1966, 55:1467-1474

13. ATCHISON RW, CASTO BC, HAMMON WM: ADENOVIRUS-ASSOCIATED DEFECTIVE VIRUS PARTICLES. Science 1965, 149:754-756

14. Parks WP, Green M, Pina M, Melnick JL: Physicochemical characterization of adeno-associated satellite virus type 4 and its nucleic acid. J Virol 1967, 1:980-987.

15. Bantel-Schaal U, zur HH: Characterization of the DNA of a defective human parvovirus isolated from a genital site. Virology 1984, 134:52-63.

16. Georg-Fries B, Biederlack S, Wolf J, zur HH: Analysis of proteins helper dependence and seroepidemiology of a new human parvovirus. Virology 1984, 134:64-71

17. Rutledge EA, Halbert CL, Russell DW: Infectious clones and vectors derived from adeno-associated virus (AAV) serotypes other than AAV type 2. J Virol 1998, 72:309-319.

18. Gao G, Vandenberghe LH, Alvira MR, Lu Y, Calcedo R, Zhou X, Wilson JM: Clades of Adeno-associated viruses are widely disseminated in human tissues. J Virol 2004, 78:6381-6388.

19. Mori S, Wang L, Takeuchi T, Kanda T: Two novel adeno-associated viruses from cynomolgus monkey: pseudotyping characterization of capsid protein. Virology 2004, 330:375-383.

20. Schmidt M, Voutetakis A, Afione S, Zheng C, Mandikian D, Chiorini JA: Adeno-associated virus Type 12 (AAV12): A novel AAV serotype with sialic acid- and heparan sulfate proteoglycan-independent transduction activity. Journal of Virology 2008, 82:1399-1406.

21. Summerford C, Samulski RJ: Membrane-associated heparan sulfate proteoglycan is a receptor for adeno-associated virus type 2 virions. Journal of Virology 1998, 72:1438-1445.

22. Di Pasquale G, Davidson BL, Stein CS, Martins IS, Scudiero D, Monks A, Chiorini JA: Identification of PDGFR as a receptor for AAV-5 transduction. Nature Medicine 2003, 9:1306-1312.

23. Wu Z, Miller E, Agbandje-McKenna M, Samulski RJ: Alpha2,3 and alpha2,6 $\mathrm{N}$-linked sialic acids facilitate efficient binding and transduction by adeno-associated virus types 1 and 6. J Virol 2006, 80:9093-9103.

24. Kaludov N, Brown KE, Walters RW, Zabner J, Chiorini JA: Adenoassociated virus serotype 4 (AAV4) and AAV5 both require sialic acid binding for hemagglutination and efficient transduction but differ in sialic acid linkage specificity. Journal of Virology 2001, 75:6884-6893.

25. Summerford C, Bartlett JS, Samulski RJ: alpha V beta 5 integrin: a coreceptor for adeno-associated virus type 2 infection. Nature Medicine 1999, 5:78-82

26. Qing K, Mah C, Hansen J, Zhou SZ, Dwarki V, Srivastava A: Human fibroblast growth factor receptor 1 is a co-receptor for infection by adeno-associated virus 2. Nature Medicine 1999, 5:71-77

27. Kashiwakura Y, Tamayose K, Iwabuchi K, Hirai Y, Shimada T, Matsumoto K, Nakamura T, Watanabe M, Oshimi K, Daida H: Hepatocyte growth factor receptor is a coreceptor for adeno-associated virus type 2 infection. Journal of Virology 2005, 79:609-614.

28. Rabinowitz JE, Rolling F, Li CW, Conrath H, Xiao WD, Xiao X, Samulski RJ: Cross-packaging of a single adeno-associated virus (AAV) type 2 vector genome into multiple AAV serotypes enables transduction with broad specificity. Journal of Virology 2002, 76:791-801.

29. Burger C, Gorbatyuk OS, Velardo MJ, Peden CS, Williams P, Zolotukhin S, Reier PJ, Mandel RJ, Muzyczka N: Recombinant AAV viral vectors pseudotyped with viral capsids from serotypes 1,2, and 5 display differential efficiency and cell tropism after delivery to different regions of the central nervous system. Mol Ther 2004, 10:302-317.
30. Klein RL, Dayton RD, Leidenheimer NJ, Jansen K, Golde TE, Zweig RM Efficient neuronal gene transfer with AAV8 leads to neurotoxic levels of tau or green fluorescent proteins. Mol Ther 2006, 13:517-527.

31. Klein RL, Dayton RD, Tatom JB, Henderson KM, Henning PP: AAV8, 9, Rh10, Rh43 vector gene transfer in the rat brain: effects of serotype promoter and purification method. Mol Ther 2008, 16:89-96.

32. Kwon I, Schaffer DV: Designer gene delivery vectors: molecular engineering and evolution of adeno-associated viral vectors for enhanced gene transfer. Pharm Res 2008, 25:489-499.

33. Reimsnider S, Manfredsson FP, Muzyczka N, Mandel RJ: Time course of transgene expression after intrastriatal pseudotyped rAAV2/1, rAAV2/ 2, rAAV2/5, and rAAV2/8 transduction in the rat. Mol Ther 2007, 15:1504-1511.

34. McFarland NR, Lee JS, Hyman BT, McLean PJ: Comparison of transduction efficiency of recombinant AAV serotypes 1, 2, 5, and 8 in the rat nigrostriatal system. J Neurochem 2009, 109:838-845.

35. Lawlor PA, Bland RJ, Mouravlev A, Young D, During MJ: Efficient gene delivery and selective transduction of glial cells in the mammalian brain by AAV serotypes isolated from nonhuman primates. Mol The 2009, 17:1692-1702.

36. de Backer M, Brans M, Luijendijk M, Garner K, Adan R: Optimization of adeno-associated viral vector mediated gene delivery to the hypothalamus. Hum Gene Ther 2010, 21:673-82.

37. Cronin J, Zhang XY, Reiser J: Altering the tropism of lentiviral vectors through pseudotyping. Curr Gene Ther 2005, 5:387-398.

38. Shin AC, Zheng H, Berthoud HR: An expanded view of energy homeostasis: neural integration of metabolic cognitive, and emotional drives to eat. Physiol Behav 2009, 97:572-580

39. Kas MJ, Tiesjema B, van Dijk G, Garner KM, Barsh GS, ter Brake O, Verhaagen J, Adan RA: Induction of brain-region-specific forms of obesity by agouti. J Neurosci 2004, 24:10176-10181.

40. Tiesjema B, la Fleur SE, Luijendijk MC, Brans MA, Lin EJ, During MJ, Adan RA: Viral mediated neuropeptide $Y$ expression in the rat paraventricular nucleus results in obesity. Obesity (Silver Spring) 2007, 15:2424-2435.

41. Tiesjema B, Adan RA, Luijendijk MC, Kalsbeek A, la Fleur SE: Differential effects of recombinant adeno-associated virus-mediated neuropeptide $\mathrm{Y}$ overexpression in the hypothalamic paraventricular nucleus and lateral hypothalamus on feeding behavior. J Neurosci 2007, 27:14139-14146

42. Grillo CA, Tamashiro KL, Piroli GG, Melhorn S, Gass JT, Newsom RJ, Reznikov LR, Smith A, Wilson SP, Sakai RR, et al:: Lentivirus-mediated downregulation of hypothalamic insulin receptor expression. Physiol Behav 2007, 92:691-701.

43. Blits B, Derks S, Twisk J, Ehlert E, Prins J, Verhaagen J: Adeno-associated viral vector (AAV)-mediated gene transfer in the red nucleus of the adult rat brain: Comparative analysis of the transduction properties of seven AAV serotypes and lentiviral vectors. J Neurosci Methods 2010 185:257-63.

44. Harvey AR, Kamphuis W, Eggers R, Symons NA, Blits B, Niclou S, Boer GJ, Verhaagen J: Intravitreal injection of adeno-associated viral vectors results in the transduction of different types of retinal neurons in neonatal and adult rats: a comparison with lentiviral vectors. $\mathrm{Mo} / \mathrm{Cell}$ Neurosci 2002, 21:141-157.

45. Nielsen TT, Marion I, Hasholt L, Lundberg C: Neuron-specific RNA interference using lentiviral vectors. J Gene Med 2009, 11:559-569.

46. Naldini L, Blomer U, Gage FH, Trono D, Verma IM: Efficient transfer integration, and sustained long-term expression of the transgene in adult rat brains injected with a lentiviral vector. Proc Natl Acad Sci USA 1996, 93:11382-11388

47. Blomer U, Naldini L, Kafri T, Trono D, Verma IM, Gage FH: Highly efficient and sustained gene transfer in adult neurons with a lentivirus vector. Journal of Virology 1997, 71:6641-6649.

48. van Hooijdonk LW, Ichwan M, Dijkmans TF, Schouten TG, de Backer MW, Adan RA, Verbeek FJ, Vreugdenhil E, Fitzsimons CP: Lentivirus-mediated transgene delivery to the hippocampus reveals sub-field specific differences in expression. BMC Neurosci 2009, 10:2.

49. Baekelandt V, Claeys A, Eggermont K, Lauwers E, De Strooper B, Nuttin B, Debyser Z: Characterization of lentiviral vector-mediated gene transfer in adult mouse brain. Hum Gene Ther 2002, 13:841-853.

50. Ahmed BY, Chakravarthy S, Eggers R, Hermens WT, Zhang JY, Niclou SP, Levelt C, Sablitzky F, Anderson PN, Lieberman AR, et al.: Efficient delivery of Cre-recombinase to neurons in vivo and stable transduction of 
neurons using adeno-associated and lentiviral vectors. BMC Neurosci 2004, 5:4.

51. Ehrengruber MU, Hennou S, Bueler H, Naim HY, Deglon N, Lundstrom K: Gene transfer into neurons from hippocampal slices: comparison of recombinant Semliki Forest Virus adenovirus, adeno-associated virus lentivirus, and measles virus. Mol Cell Neurosci 2001, 17:855-871.

52. Rabinowitz JE, Bowles DE, Faust SM, Ledford JG, Cunningham SE, Samulski $\mathrm{RJ}$ : Cross-dressing the virion: the transcapsidation of adeno-associated virus serotypes functionally defines subgroups. Journal of Virology 2004, 78:4421-4432.

53. Davis HE, Morgan JR, Yarmush ML: Polybrene increases retrovirus gene transfer efficiency by enhancing receptor-independent virus adsorption on target cell membranes. Biophys Chem 2002, 97:159-172.

54. Nathanson JL, Yanagawa Y, Obata K, Callaway EM: Preferential labeling of inhibitory and excitatory cortical neurons by endogenous tropism of adeno-associated virus and lentivirus vectors. Neuroscience 2009 161:441-450

55. Schlegel R, Tralka TS, Willingham MC, Pastan I: Inhibition of VSV binding and infectivity by phosphatidylserine: is phosphatidylserine a VSVbinding site? Cell 1983, 32:639-646.

56. Coil DA, Miller AD: Phosphatidylserine is not the cell surface receptor for vesicular stomatitis virus. J Virol 2004, 78:10920-10926.

57. Shevtsova Z, Malik JM, Michel U, Bahr M, Kugler S: Promoters and serotypes: targeting of adeno-associated virus vectors for gene transfer in the rat central nervous system in vitro and in vivo. Exp Physiol 2005, 90:53-59.

58. Jakobsson J, Ericson C, Jansson M, Bjork E, Lundberg C: Targeted transgene expression in rat brain using lentiviral vectors. J Neurosci Res 2003, 73:876-885

59. Mazarakis ND, Azzouz M, Rohll JB, Ellard FM, Wilkes FJ, Olsen AL, Carter EE, Barber RD, Baban DF, Kingsman SM, et al:: Rabies virus glycoprotein pseudotyping of lentiviral vectors enables retrograde axonal transport and access to the nervous system after peripheral delivery. Hum Mol Genet 2001, 10:2109-2121.

60. Eaton MJ, Blits B, Ruitenberg MJ, Verhaagen J, Oudega M: Amelioration of chronic neuropathic pain after partial nerve injury by adenoassociated viral (AAV) vector-mediated over-expression of BDNF in the rat spinal cord. Gene Ther 2002, 9:1387-1395.

61. Broekman MLD, Comer LA, Hyman BT, Siena-Esteves M: Adenoassociated virus vectors serotyped with AAV8 capsid are more efficient than AAV-1 or-2 serotypes for widespread gene delivery to the neonatal mouse brain. Neuroscience 2006, 138:501-510.

62. Fitzsimons $\mathrm{CP}$, Ahmed S, Wittevrongel $\mathrm{CF}$, Schouten TG, Dijkmans TF, Scheenen WJ, Schaaf MJ, de Kloet ER, Vreugdenhil E: The microtubuleassociated protein doublecortin-like regulates the transport of the glucocorticoid receptor in neuronal progenitor cells. Mol Endocrinol 2008, 22:248-262.

63. Stegmeier F, Hu G, Rickles RJ, Hannon GJ, Elledge SJ: A lentiviral microRNA-based system for single-copy polymerase II-regulated RNA interference in mammalian cells. Proc Natl Acad Sci USA 2005, 102:13212-13217.

64. Reed SE, Staley EM, Mayginnes JP, Pintel DJ, Tullis GE: Transfection of mammalian cells using linear polyethylenimine is a simple and effective means of producing recombinant adeno-associated virus vectors. Journal of Virological Methods 2006, 138:85-98.

65. Grimm D, Kay MA, Kleinschmidt JA: Helper virus-free, optically controllable and two-plasmid-based production of adeno-associated virus vectors of serotypes 1 to 6 . Mol Ther 2003, 7:839-850

66. Zolotukhin S, Potter M, Zolotukhin I, Sakai Y, Loiler S, Fraites TJ Jr, Chiodo VA, Phillipsberg T, Muzyczka N, Hauswirth WW, et al:: Production and purification of serotype 1,2 , and 5 recombinant adeno-associated viral vectors. Methods 2002, 28:158-167.

67. Veldwijk MR, Topaly J, Laufs S, Hengge UR, Wenz F, Zeller WJ, Fruehauf S: Development and optimization of a real-time quantitative PCR-based method for the titration of AAV-2 vector stocks. Mol Ther 2002, 6:272-278.

68. Scherr M, Battmer K, Blomer U, Ganser A, Grez M: Quantitative determination of lentiviral vector particle numbers by real-time PCR. Biotechniques 2001, 31: 520, 522, 524, passim doi: $10.1186 / 1471-2202-11-81$

Cite this article as: de Backer et al., An adeno-associated viral vector transduces the rat hypothalamus and amygdala more efficient than a lentiviral vector BMC Neuroscience 2010, 11:81

\section{Submit your next manuscript to BioMed Central and take full advantage of:}

- Convenient online submission

- Thorough peer review

- No space constraints or color figure charges

- Immediate publication on acceptance

- Inclusion in PubMed, CAS, Scopus and Google Scholar

- Research which is freely available for redistribution
C Biomed Central 